\title{
Zeolite Applications in Agriculture
}

\author{
Majid Gholamhoseini ${ }^{1 *}$ and Farhad Bagheri ${ }^{2}$ \\ ${ }^{1}$ Seed and Plant Improvement Institute, Iran \\ ${ }^{2}$ Department of Crop Science and Plant Breeding, Shahed University, Iran
}

Submission: January 26, 2018; Published: February 08, 2018

"Corresponding author: Majid Gholamhoseini, Seed and Plant Improvement Institute, Agricultural Research, Education and Extension Organization (AREEO), Iran, Tel: +98 26-36703771; Fax: +98-026-36702051, Email: mgholamhoseini@spii.com

\section{Introduction}

Due to many difficulties caused by overuse of chemicals in agriculture during recent years, much attention has been focused on sustainable agriculture concept. Sustainable agriculture provides safe and enough food for human kind and does not damage environment. Zeolites are crystalline porous aluminosilicates containing alkali (e.g. $\mathrm{Na}$ ) and alkaline earth (e.g. Ca) cations. The unique physical and chemical properties of natural zeolites, based on their ion exchange, catalytic and molecular sieve properties, make them useful for many agricultural and horticultural applications and also fore other environmental use. The present paper reviews the properties of natural zeolites in favour of sustainable agriculture.

\section{Soil Conditioner}

Despite of other soil conditioners like lime, zeolites do not break down over time but remains in the soil to improve nutrient retention [1]. Therefore its addition to soil will significantly reduce water and fertilizer costs by retaining beneficial nutrients in the root zone. Zeolite is marginally alkaline and its use with fertilizers can help buffer soil pH levels. Mumpton [2] reported that zeolites tuff doze modified soil $\mathrm{pH}$ to neutral field. The porous structure of natural zeolites helps to keep the soil aerated and moist as well as active for a long time.

\section{Fertilizer Use Efficiency}

Nitrogen (N) loss from irrigated cropland, particularly sandy soils, significantly contributes to nitrate contamination in surface and groundwater. Also it decreases fertilizer use efficiency in which enhances the costs. Gholamhoseini et al. [1] investigated the use of zeolite as organic fertilizer carriers to control $\mathrm{N}$ release in soil and reported that zeolite-amended cattle manure has a great potential to control the release of $\mathrm{N}$ and other nutrients. Zeolites added to fertilizers help to retain nutrients and, therefore, improving the long term soil quality by enhancing its absorption ability. It concerns the most important plant nutrients such as nitrogen $(\mathrm{N})$ and potassium $(\mathrm{K})$, and also calcium, magnesium and micro-elements [3,4]. Zeolite can retain these nutrients in the root zone to be used by plants when required. Consequently this leads to the more efficient use of $\mathrm{N}$ and $\mathrm{K}$ fertilizers by reducing their rates for the same yield, by prolonging their activity or finally by producing higher yields. Large losses of fertilizers which move out of the root zone (leaching) often happen in sandy soils, which lose their capability to retain high nutrient levels. Therefore an application of zeolites will enhance the plant growth and development by reducing the loss of nutrients [5].

\section{Water Supply}

Water saturation percentage (SP) is amount of water that soil can hold by overcoming the gravity force. In zeolites, saturation percentage reaches to $60 \%$ [5]; therefore it acts as a clay soil and hold high amounts of water while gives up its water to plants easily and act as a sandy soil.

\section{Removal of Heavy Metal Cations}

Many toxic heavy metals have been discharged into the environment as industrial wastes, causing serious soil and water pollution. The use of alternative low-cost materials as potential sorbents for the removal of heavy metals has been emphasized recently. The structures of zeolites consist of three dimensional frameworks of $\mathrm{SiO} 4$ and $\mathrm{AlO} 4$ tetrahedra. The aluminumion is small enough to occupy the position in the center of the tetrahedron of four oxygen atoms, and the isomorphousre placement of Si by $\mathrm{Al} 3+$ produces a negative charge in the lattice. The net negative charge is balanced by the exchangeable cation (sodium, potassium, or calcium). These cations are exchangeable with certain cations in solutions such as lead, cadmium, zinc, and manganese. [6] Showed that use of natural zeolite decreased the amount of $\mathrm{Cu}+2, \mathrm{Fe} 3+$ and $\mathrm{Cr}+3$ in a simulated soil solution.

\section{Conclusion}

The results of the review showed that zeolites are used as soil conditioner in farm lands and are used to promote better plant growth by improving the efficiency of fertilizers. zeolite also acts as a filter to removal of heavy metals by adsorbing them due to the cation exchange capacity. 


\section{References}

1. Gholamhoseini M, Ghalavand A, Joghan AK, Dolatabadian A, Zakikhani $\mathrm{H}$, et al. (2013) Zeolite-amended cattle manure effects on sunflower yield, seed quality, water use efficiency and nutrient leaching. Soil \& Tillage Research 126: 193-202.

2. Mumpton FA (1999) La roca magica: uses of natural zeolite in agriculture and industry. Proceeding of the National Academy 96: 3463-4347.

3. Gholamhoseini M, Aghaalikhani M, Dolatabadian A, Joghan AK , Zakikhani H (2012) Decreasing N leaching and increasing canola forage yield in a sandy soil by application of natural zeolite. Agronomy Journal 104: 1467-1475.

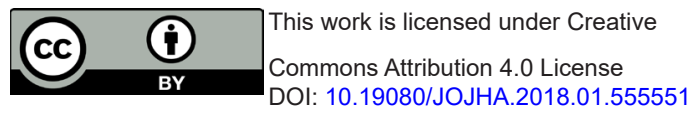

4. Gholamhoseini M, Aghaalikhani M, Malakouti MJ, Joghan AK (2012) Influence of nitrogen fertilization and zeolite application on nitrogen loss and efficiency and canola yield in sandy soil. Communications in Soil Science and Plant Analysis 43: 1247-1262.

5. Gholamhoseini M, Ghalavand A, Dolatabadian A, Jamshidi E, Joghan AK (2010) Integrated fertilizer management to attain sunflower sustainable production under different irrigation regimes. Archives of Agronomy and Soil Science 56(3): 295-309.

6. Inglezakis VJ, Zorpas AA, Loizidou MD, Grigoropoulou HP (2003) Simultaneous removal of metals $\mathrm{Cu}^{+2}, \mathrm{Fe}^{+3}$ and $\mathrm{Cr}^{+3}$ with anions $\mathrm{SO}_{4}^{-2}$ and $\mathrm{HPO}_{4}^{-2}$ using clinoptilolite. Microporous and Mesoporous Materials 61: $167-171$.

\begin{tabular}{|l|}
\hline \multicolumn{1}{|c|}{ Your next submission with Juniper Publishers } \\
will reach you the below assets \\
- Quality Editorial service \\
- Swift Peer Review \\
- Reprints availability \\
- E-prints Service \\
- Manuscript Podcast for convenient understanding \\
- Global attainment for your research \\
- Manuscript accessibility in different formats \\
( Pdf, E-pub, Full Text, Audio) \\
- Unceasing customer service \\
Track the below URL for one-step submission \\
https://juniperpublishers.com/online-submission.php
\end{tabular}

